Article

\title{
Regional Ethnocentrism on the Food Market as a Pattern of Sustainable Consumption
}

\author{
Paweł Bryła \\ Department of International Marketing and Retailing, Faculty of International and Political Studies, \\ University of Lodz, Narutowicza 59a, 90-131 Lodz, Poland; pawel.bryla@uni.lodz.pl; Tel.: +48-426655830
}

Received: 24 October 2019; Accepted: 12 November 2019; Published: 14 November 2019

\begin{abstract}
The paper aims to assess the level and predictors of regional ethnocentrism on the market of regional food products in the context of sustainable consumption. The study contributes to the theory of consumer ethnocentrism by extending our knowledge about its regional dimension. Regional ethnocentrism is the preference for products originating from the consumer's region. I conducted a survey in a representative sample of 1000 inhabitants of Poland with the use of the CAWI (Computer-Assisted Web Interview) methodology. Regional ethnocentric consumers were characterized by a significantly more favorable attitude to regional food products compared to the rest of the sample. In a multiple regression model, the following eight statistically significant predictors of the regional ethnocentrism were identified: the importance of brand and retailer trust on the food market; the importance of quality signs in regional food purchases; opinion that insufficient marketing constitutes an important barrier to the development of the regional food market; buying regional products in shops owned by producers, rather than large distribution networks; frequency of purchasing regional products as a tourist; and national ethnocentrism on the regional food market. These predictors are strongly related to the three major pillars of sustainable development-economic, social, and ecological.
\end{abstract}

Keywords: regional ethnocentrism; sustainable consumption; three pillars of sustainable development; local food; regional food; origin food; quality signs; consumer behavior on the food market; country-of-origin effect; region-of-origin effect

\section{Introduction}

Sustainable consumption and production are identified as essential requirements for sustainable development $[1,2]$. Drawing from the growing body of research on sustainable consumption and production, Bengtsson, Alfredsson, Cohen, Lorek, and Schroeder [3] identified two dominant vantage points-one focused on promoting more efficient production methods and products (mainly through technological improvement and informed consumer choice), and the other stressing the need to consider also overall volumes of consumption, distributional issues, and related social and institutional changes. Sustainable consumption can encompass both sustainable attitudes and sustainable behaviors [4]. There is an "attitude-behavior gap" or "values-action gap," as 30\% of consumers report that they are very concerned about environmental issues but are struggling to translate this into purchases [5]. Securing public participation in recycling, energy conservation measures, and green consumerism is a means of progressing toward sustainable consumption [6]. More sustainable food consumption can be stimulated through raising involvement, perceived consumer effectiveness, certainty, social norms, and perceived availability [7]. Drawing on signaling theory, Brach, Walsh, and Shaw [8] showed that third-party certification labels on sustainable products provide brand-like information cues that reduce the perceived risk of sustainable products, but consumers must perceive them as credible to have their risk perceptions reduced. Onel et al. [9] adopted personas as a way to better 
explain and understand the holistic nature and complexity of sustainable consumer behavior in terms of its various stages (i.e., acquisition, usage, and post-use) within key behavioral functions of mobility, housing, clothing, and food. Sustainable consumption is associated with the reduction of food waste [10] and eating organic food [11-13] and local food [14], among other activities. Ecological citizenship is a driving force for "alternative" sustainable consumption expressed by purchasing local organic food [15]. Farmers' markets have the potential to encourage sustainable agricultural production and consumption [16]. Networks of producers, consumers, and other actors can act to improve food sustainable and anti-consumption behaviors by embodying alternatives to conventional food systems [17]. Anti-consumption literally means "against consumption," but the word is not synonymous with alternative, conscientious, or green consumption. Although some consumers may affirm their anti-consumption attitudes through non-standard consumption or lifestyle choices, anti-consumption research focuses on reasons against consumption rather than pro-social movements [18]. Access to sustainable food is not necessarily determined by financial means only, nor by individual attitudes, but should be analyzed as embedded in the complex dynamics of multiple social practices [19]. In this paper, I argue that the preference for food products originating from one's own region (called regional ethnocentrism) constitutes a pattern of sustainable consumption.

Consumer ethnocentrism has usually been studied at the national level. Its antecedents are socio-psychological, political, economic and demographic [20]. Consumer ethnocentrism is a multidimensional construct that encompasses prosociality, cognition, insecurity, reflexiveness, and habituation [21]. However, it may also be observed at other levels of analysis, including the preference for products originating from one's own region. Consumer ethnocentrism is an important factor regarding the intention to purchase not only foreign products but also non-regional products [22]. The region of origin has a product-specific influence on product preference [23]. On average, consumers are willing to pay a premium for local food [24]. Most consumers view food as local if it is sold in the same state as it was grown [25]. Health consciousness, concern for the environment, and concern for local economies were found to be significant predictors of attitude toward local food [26]. Trust and a sense of personal connection with the farmer comprise part of the "value added" of community-supported agriculture (CSA) participation [27]. The findings of Siemieniako, Kubacki, Glińska, and Krot [28] point to the relative importance of elements such as brand image (based on Polish culture and referring to its symbols), local brands as contributors to local identities and the form of their expression, as well as a moral obligation to buy local brands. Consumers' image of regional certification labels consists of a quality warranty dimension and an economic support dimension, which positively relate to consumers' willingness to buy and pay for the protected regional product [29]. The most important marketing consequences of implementing the European Union system of origin product protection consist in image enhancement, distribution policy innovations, and refreshing the marketing strategy of the organization [30]. Polish consumers underlined the role of quality signs in positioning origin and organic products in the segment of premium prices, building competitive advantage on the basis of the differentiation strategy, and emphasizing authenticity [31]. Levels of consumer ethnocentrism are sometimes (but not always) related to the actual purchase of local-regional-traditional food products [32]. Great importance is also attached to the origin of financial entities, with a preference of regional over national or foreign institutions, but the place-of-origin effect is not universal [33]. Consumer ethnocentrism, along with regional image and perceived quality, affect the intention to choose regional banks [34]. Regional ethnocentrism is a general tendency acquired during childhood through the process of socialization [35]. There is a relationship between national ethnocentrism and regional ethnocentrism on the organic food market [36]. I apply the term "regional ethnocentrism" referring to subnational regions, although in it may also refer to the region understood as a group of countries, e.g., ASEAN (Association of South-East Asian Nations) [37].

As consumer ethnocentrism has usually been studied at the national level, there is a research gap concerning its regional dimension. Bearing in mind that the region-of-origin effects, including regional consumer ethnocentrism, are product-specific and country-specific, there is little extant research in 
this field related to regional food products and the attitudes of Polish consumers. Who are regional ethnocentric consumers? What factors influence the level of regional ethnocentrism? The paper aims to assess the level and predictors of regional ethnocentrism on the market of regional food products in the context of sustainable consumption. This is exploratory research. Therefore, no research model and hypotheses are formulated a priori. The main research questions are about the size and characteristics of the segment of regional ethnocentric consumers and the identification of selected antecedents of regional ethnocentrism on the food market. This paper will assess the importance attached to food products originating from the consumer's own region in the following three categories: regional, organic, and conventional products. Furthermore, it will compare the segment of regional ethnocentric consumers with the rest of the sample in order to get to know selected attitudes and behavior of this type of consumer. The comparisons will concern the share of regional products in total food purchases, the willingness to pay a higher price for regional products compared to conventional food, the share of products from one's own region in one's purchases of regional food, the importance of selected characteristics of food products, the role of quality signs in conventional and regional food purchases, national ethnocentrism in conventional and regional food purchases, opinions on regional food products compared to the conventional food, authenticity assessment criteria for regional food products, the importance of barriers to the development of the market of regional food products, food selection motives, and the distribution channels used for regional food products. The selected variables are important from the perspective of improving marketing strategies in the field of regional food products. Their choice stems to a large extent from previous research on marketing regional food products from the perspective of European producers [38]. In a series of regression studies, I will identify selected predictors of regional ethnocentrism on the food market. In the discussion, I will try to relate these predictors of regional ethnocentrism to the three pillars of sustainable development.

Poland was chosen as the research setting because it is a relatively big country (38 million inhabitants), a European Union member, and has a unitary administrative structure and an ethnically homogeneous population. Therefore, the results are not biased by potential impacts of the existence of multiple nationalities in the same country (e.g., Basque in Spain, Scottish in the UK), ethnic minorities (e.g., Turkish in Germany, Algerian in France), or administrative autonomy at the regional level.

This study contributes to the theory of consumer ethnocentrism by extending our knowledge about its regional dimension. The paper is organized as follows. The Materials and Methods section explains the sampling criteria and the operationalization of key variables used in this study. The Results section presents all the major findings concerning the characteristics of regional ethnocentric consumers and predictors of regional ethnocentrism. The Discussion section comments on selected results, referring them to the concept of sustainable consumption (with the use of the framework of three pillars of sustainable development), and comparing them to findings concerning organic food consumption in Poland. The Conclusions section provides theoretical and managerial implications of my findings as well as discusses the limitations of this study and future research directions.

\section{Materials and Methods}

A survey was addressed to Polish consumers. The sample consisted of 1000 inhabitants of Poland aged 15-65. The sample size was set at a comparable level with previous consumer studies conducted at the national level in Poland (e.g., references [39,40]). It was aimed to obtain a sample resembling the general population of Polish adults, regarding four criteria: age, sex, education level, and the size of the city of origin (in particular the urban/rural divide). The sample was representative for the general population, regarding age, sex, education, and the size of the city of origin, with the exception of the age group of over 65, which was not included in the sample. It was a non-probability quota sample. The survey was carried out with the use of the computer-assisted web interview (CAWI) method by a specialized marketing research agency (ARC Rynek i Opinia, Warsaw, Poland) in its online panel (epanel.pl). Whenever a catalogue of options was proposed, the respondents had the possibility to supplement it with their own answer (semi-open questions) so as to ensure that the respondents' 
opinions are reflected to the highest degree in the research results. The questionnaire was designed in Polish due to the research setting. It is available from the author upon request.

The operationalization of key variables with the measurement scales is provided in Table 1. It is based on previous research among regional food producers [38] as well as among distributors and young consumers on the food market [41]. Selected scales were adapted from reference [42]. The conceptualization of the phenomenon of regional ethnocentrism refers to the perceived importance of the origin of products from the region where the consumer lives. Contrary to the classical (national) ethnocentrism, regional ethnocentrism is defined at the subnational level.

Table 1. The operationalization of key variables used in this study.

\begin{tabular}{|c|c|c|}
\hline Variable & Operationalization & Measurement Scale and Coding \\
\hline Regional ethnocentrism & $\begin{array}{l}\text { How important for you is the } \\
\text { origin of the product from the } \\
\text { same region that you live in? }\end{array}$ & $\begin{array}{l}\text { Measured separately for "ordinary" (conventional) food, regional } \\
\text { products, and organic products: very important-5, rather } \\
\text { important-4, average-3, rather not important-2, completely not } \\
\text { important-1 }\end{array}$ \\
\hline National ethnocentrism & $\begin{array}{l}\text { How important for you is the } \\
\text { origin of the product from Poland? }\end{array}$ & $\begin{array}{l}\text { Measured separately for "ordinary" (conventional) food, and regional } \\
\text { products: very important }-5 \text {, rather important }-4 \text {, average }-3 \text {, rather } \\
\text { not important }-2 \text {, completely not important }-1\end{array}$ \\
\hline $\begin{array}{l}\text { Importance of selected } \\
\text { characteristics of food products }\end{array}$ & $\begin{array}{l}\text { How important for you are the } \\
\text { following characteristics of food } \\
\text { products? }\end{array}$ & $\begin{array}{l}\text { Measured separately for area of origin, price, quality signs, brand, trust } \\
\text { in the point of sale (retailer), product appearance: very important- }-5 \text {, } \\
\text { rather important- } 4 \text {, average- }-3 \text {, rather not important-2, completely } \\
\text { not important-1 }\end{array}$ \\
\hline $\begin{array}{l}\text { Share of regional products in total } \\
\text { food purchases }\end{array}$ & $\begin{array}{l}\text { What is the share of regional } \\
\text { products in your food purchases? }\end{array}$ & $\%$ \\
\hline $\begin{array}{l}\text { Willingness to pay a higher price } \\
\text { for regional products }\end{array}$ & $\begin{array}{l}\text { You are willing to pay a higher } \\
\text { price for regional products } \\
\text { compared to 'ordinary' food by } \\
\text { how much? }\end{array}$ & $\%$ \\
\hline $\begin{array}{l}\text { Share of products from one's own } \\
\text { region in one's purchases of } \\
\text { regional food }\end{array}$ & $\begin{array}{l}\text { What share of regional products } \\
\text { that you buy constitute products } \\
\text { originating from your own region? }\end{array}$ & $\%$ \\
\hline $\begin{array}{l}\text { Role of quality signs in food } \\
\text { purchases }\end{array}$ & $\begin{array}{l}\text { To what an extent are you driven } \\
\text { by quality signs in food purchases? }\end{array}$ & $\begin{array}{l}\text { Measured separately for "ordinary" (conventional) and regional food: } \\
\text { very large }-5 \text {, rather large }-4 \text {, average }-3 \text {, rather small }-2 \text {, none }-1\end{array}$ \\
\hline $\begin{array}{l}\text { Opinions on regional food } \\
\text { products }\end{array}$ & $\begin{array}{l}\text { Do you agree with the following } \\
\text { opinions on regional products in } \\
\text { comparison with the "ordinary" } \\
\text { (conventional, mass) food? }\end{array}$ & $\begin{array}{l}\text { measured separately for the following items: they have a better quality; } \\
\text { they are more expensive; they are more authentic; they are more tasty; } \\
\text { they are produced in a more traditional way; they are more } \\
\text { environmentally friendly; they are subject to more strict controls; they } \\
\text { are healthier; they arouse more trust; their advertising is better; they } \\
\text { look better; I accept their higher price; Irecommend their purchases to } \\
\text { my family/friends: definitely yes- }-5 \text {, rather yes-4, I don't know-3, } \\
\text { rather not-2, definitely not-1 }\end{array}$ \\
\hline $\begin{array}{l}\text { Authenticity assessment criteria } \\
\text { for regional food products }\end{array}$ & $\begin{array}{l}\text { Please choose three most } \\
\text { important factors on the basis of } \\
\text { which one can assess the } \\
\text { authenticity of regional products. }\end{array}$ & $\begin{array}{l}\text { The choice of up to three out of the following } 14 \text { criteria: consumer } \\
\text { knowledge, low availability of such products, name of the product } \\
\text { (brand), label, look of the product, packaging, point of sale - shop type, } \\
\text { sale in the region of origin, addressing offer to tourists, European } \\
\text { quality sign, product quality, natural taste, separate exposition place in } \\
\text { shops, other. }\end{array}$ \\
\hline $\begin{array}{l}\text { Barriers to the development of the } \\
\text { market of regional food products }\end{array}$ & $\begin{array}{l}\text { Please identify three most } \\
\text { important barriers to the } \\
\text { development of the market of } \\
\text { regional products. }\end{array}$ & $\begin{array}{l}\text { The choice of up to three out of the following } 12 \text { barriers: high price, } \\
\text { unfavorable appearance of products, low availability, satisfaction with } \\
\text { the consumption of "ordinary" food, low visibility in the point of sale, } \\
\text { skepticism toward the systems of certification and labelling, insufficient } \\
\text { intensity of marketing activities, mistakes in marketing strategies, } \\
\text { worse taste in comparison with "ordinary" products, short expiry dates; } \\
\text { insufficient consumer knowledge, other. }\end{array}$ \\
\hline Food selection motives & $\begin{array}{l}\text { What decides about the choice of } \\
\text { food products? Please choose five } \\
\text { motives. }\end{array}$ & $\begin{array}{l}\text { Measured separately for regional products and "ordinary: } \\
\text { (conventional) food; the choice of up to five out of the following } 26 \\
\text { motives: producer brand and reputation, quality assurance (certificate, } \\
\text { sign), traditional recipe, ecological character of the product, product } \\
\text { identification with an area of origin, concern for animal welfare, } \\
\text { concern for local producers, nostalgia, fashion for consuming such food, } \\
\text { curiosity, loyalty, traceability, price, taste, smell, healthiness, food safety, } \\
\text { expiry date, product uniqueness, brand and reputation of the point of } \\
\text { sale, availability near one's place of living, consumption pleasure, } \\
\text { richness in minerals and vitamins, advertising, opinions of } \\
\text { family/friends, other. }\end{array}$ \\
\hline $\begin{array}{l}\text { Distribution channels used for } \\
\text { regional food products }\end{array}$ & $\begin{array}{l}\text { Where do you buy regional } \\
\text { products? }\end{array}$ & $\begin{array}{l}\text { A multiple-choice question with the following answer options: on the } \\
\text { farm, producer-owned shops, markets, bazaars, fairs, festivals, } \\
\text { specialized shops with organic food, independent groceries, large } \\
\text { distribution networks (hypermarkets, supermarkets, discount stores } \\
\text { etc.), restaurants, internet, other. }\end{array}$ \\
\hline $\begin{array}{l}\text { Purchasing regional food products } \\
\text { as a tourist }\end{array}$ & $\begin{array}{l}\text { As a tourist, do you buy regional } \\
\text { food products in the country or } \\
\text { region that you visit? }\end{array}$ & $\begin{array}{l}\text { Very often }-5 \text {, rather often }-4 \text {, with average frequency }-3 \text {, rather } \\
\text { seldom }-2, \text { not at all }-1\end{array}$ \\
\hline
\end{tabular}


Women constitute $50.1 \%$ of the study subjects, which is slightly less than in the general population of Poland (51.6\% according to Central Statistical Office [43] (p. 195)). The age of the study subjects ranges from 15 to 65 , with the mean of 40 . The age structure of the sample corresponds very well with the general population of Poles belonging to this age interval [43] (p. 196). As far as education level is concerned, $42.0 \%$ of the study subject have only completed primary school, $36.8 \%$ have secondary education, and $21.1 \%$ graduated from a higher education institution. These figures are also similar to the general population [43] (p. 199). All the 16 Polish regions are represented in the sample. The sample also resembles the general population regarding the size of the city of origin [43] (pp. 204-207). The proportion between inhabitants of urban and rural areas is almost identical as in the general population (39.0\% of the study subjects live in the countryside compared to $39.4 \%$ of Poles). A more detailed comparison of the sample with the general population may be found in a previous article from the same research project [44].

This paper focuses on the importance attached to regional food products originating from the consumer's region of residence. Descriptive statistics, $\chi^{2}$ tests, $t$-tests, simple and multiple regression models were applied. The analyses were conducted in Microsoft Excel 2013 (Microsoft, Redmond, Washington, the United States of America) and Statistica 12.0 (TIBCO Software Inc., Palo Alto, California, the United States of America).

\section{Results}

The importance attached to the product originating from the consumer's region is higher for regional food than for organic food or conventional food (Table 2). Here, $25.5 \%$ of the study subjects attached very high importance to this factor on the regional food market, while it was $17.5 \%$ for organic food and $13.4 \%$ for conventional food. Only for $6.7 \%$ of respondents, the information that a regional product comes from their own region is of no importance.

Table 2. The importance attached to food products originating from the consumer's own region (\%).

\begin{tabular}{cccccc}
\hline Food Products & Very High & Rather High & Average & Rather Low & None \\
\hline Regional & 25.5 & 32.7 & 28.0 & 7.1 & 6.7 \\
Organic & 17.5 & 30.2 & 32.4 & 10.4 & 9.5 \\
Conventional & 13.4 & 26.6 & 37.5 & 11.3 & 11.2 \\
\hline
\end{tabular}

First, I identified respondents who reported very high importance of regional food products originating from their region of residence, calling them regional ethnocentric consumers (255 people), and compared their characteristics, attitudes and opinions with the rest of the sample (745 people). These subsamples had a similar gender composition $(48.2 \%$ of females v. $50.7 \%$ of females, Yates $\chi^{2}=0.381, p=0.537$ ). They did not differ significantly by age (mean $=39.93$ v. $38.97, t=0.953$, $p=0.341$ ), though slightly higher levels of regional ethnocentrism were observed in the age groups 35-44 and 55-65. The place of residence, understood as the size of the city, did not affect regional ethnocentrism in a significant way $\left(\chi^{2}=9.844, p=0.131\right)$, but this attitude tended to be more common among inhabitants of small and medium cities (50,000-200,000 inhabitants). The level of education did not affect regional ethnocentrism $\left(\chi^{2}=3.145, p=0.207\right)$, even if it was lower among respondents with tertiary education. No statistically significant impacts of professional activity $\left(\chi^{2}=6.451, p=\right.$ $0.375)$, household size $(t=0.121, p=0.903)$, and income $(t=1.028, p=0.304)$ were observed either. Therefore, it seems that demographic and socioeconomic criteria have limited power in explaining the phenomenon of regional ethnocentrism on the food market.

In accordance with my expectations, regional ethnocentric respondents tend to buy more regional food products than the rest of the sample, are willing to pay a higher price for regional food than for conventional food, and tend to select regional products from their own region more often in purchasing regional food (Table 3). For the last variable, it needs to be explained that regional food products may come from the region of consumer but also from other regions of the same country, and even 
from abroad. What differentiates regional products is the emphasis on the region of origin and not necessarily originating from the same region as the consumer. This emphasis may be strengthened by obtaining a European quality sign for regional products (Protected Designation of Origin or Protected Geographical Indication). Regional food products in this sense may also be called origin food [44].

Table 3. A comparison of regional ethnocentric consumers with the rest of the sample regarding the share of regional products in total food purchases, the willingness to pay a higher price for regional products compared to conventional food, and the share of products from one's own region in one's purchases of regional food.

\begin{tabular}{ccccccc}
\hline \multirow{2}{*}{ Measure } & \multicolumn{2}{c}{ Regional (\%) } & \multicolumn{2}{c}{ WTP (\%) } & \multicolumn{2}{c}{ Own Region (\%) } \\
\cline { 2 - 6 } & RE & Other & RE & Other & RE & Other \\
\hline Mean & 38.3 & 27.3 & 19.6 & 16.0 & 44.4 & 27.1 \\
Standard Deviation & 24.5 & 22.8 & 16.9 & 16.1 & 29.0 & 26.4 \\
Variation & 0.638 & 0.836 & 0.864 & 1.001 & 0.653 & 0.974 \\
Minimum & 1 & 1 & 0 & 0 & 0 & 0 \\
1st quartile & 20 & 10 & 10 & 5 & 20 & 5 \\
Median & 30 & 20 & 20 & 10 & 40 & 20 \\
3rd quartile & 60 & 45 & 25 & 20 & 70 & 46.25 \\
Maximum & 100 & 100 & 100 & 100 & 100 & 100 \\
\hline Notes: RE-regional ethnocentric consumers (255 respondents), Other-the rest of the sample (745 respondents).
\end{tabular}

Regional ethnocentric consumers attach higher importance to certain characteristics of food products in a statistically significant way compared to the rest of the sample (Table 4 ). The biggest differences were observed for quality signs, area of origin, and retailer trust $(t>7, p<0.001)$. The most important characteristics of food products for regional ethnocentric consumers are price, trust in the retailer, and product appearance.

Table 4. A comparison of regional ethnocentric consumers with the rest of the sample regarding the importance of selected characteristics of food products.

\begin{tabular}{ccccc}
\hline \multirow{2}{*}{ Importance of the Following Characteristics } & \multicolumn{2}{c}{ Mean } & \multirow{2}{*}{$\mathbf{t}$} & p \\
\cline { 2 - 3 } & RE & Other & & \\
\hline Price & 4.475 & 4.330 & 2.765 & 0.006 \\
Retailer trust & 4.290 & 3.803 & 7.503 & $<0.001$ \\
Product appearance & 4.267 & 3.950 & 4.960 & $<0.001$ \\
Quality signs & 4.255 & 3.756 & 7.864 & $<0.001$ \\
Area of origin & 3.977 & 3.393 & 7.786 & $<0.001$ \\
Brand & 3.788 & 3.404 & 5.786 & $<0.001$ \\
\hline
\end{tabular}

Notes: RE-regional ethnocentric (255 respondents), Other—the rest of the sample (745 respondents); 1-5 scale.

The role of quality signs in food purchases was significantly higher among regional ethnocentric consumers in comparison with the rest of the sample (Table 5). This attribute was significantly more important both for regional food products and conventional food products. 
Table 5. A comparison of regional ethnocentric consumers with the rest of the sample regarding the role of quality signs in conventional and regional food purchases.

\begin{tabular}{cccccc}
\hline \multirow{2}{*}{ Role of Quality Signs } & \multicolumn{2}{c}{ Mean } & \multirow{2}{*}{$\mathbf{t}$} & p \\
\cline { 2 - 3 } & RE & Other & & \\
\hline Regional food & 4.008 & 3.067 & 12.962 & $<0.001$ \\
Conventional food & 3.388 & 3.012 & 4.869 & $<0.001$ \\
\hline
\end{tabular}

Notes: RE-regional ethnocentric (255 respondents), Other-the rest of the sample (745 respondents); $1-5$ scale.

Regional ethnocentric consumers are characterized by a strong preference for products originating from their country of origin, which I call national ethnocentrism (Table 6). The phenomenon of national ethnocentrism applies both to conventional food and to regional food purchases.

Table 6. A comparison of regional ethnocentric consumers with the rest of the sample regarding national ethnocentrism in conventional and regional food purchases.

\begin{tabular}{cccccc}
\hline \multirow{2}{*}{ National Ethnocentrism } & \multicolumn{2}{c}{ Mean } & \multirow{2}{*}{$\mathbf{t}$} & $\mathbf{p}$ \\
\cline { 2 - 3 } & $\mathbf{R E}$ & Other & & \\
\hline Regional food & 4.776 & 3.831 & 14.405 & $<0.001$ \\
Conventional food & 4.424 & 3.679 & 10.298 & $<0.001$ \\
\hline
\end{tabular}

Notes: RE-regional ethnocentric (255 respondents), Other-the rest of the sample (745 respondents); $1-5$ scale.

The respondents were asked to express their opinions on selected comparisons of regional food products with the conventional (mass) food. Table 7 shows a comparison of the responses between regional ethnocentric respondents and the rest of the sample. Regional ethnocentric respondents differed considerably from the rest of the sample in terms of all the examined opinions except one. The largest differences were noted for the opinions that regional products have a better quality, arouse more trust, are more tasty, are healthier, are more authentic, are produced in a more traditional way, and the respondent recommends their purchases to his or her family or friends $(t>10, p<0.001)$. The only opinion that did not differ significantly between regional ethnocentric consumers and the other respondents was that the advertising for regional products is better than for conventional food. The strongest beliefs about regional food products among regional ethnocentric consumers are that they are more tasty, are produced in a more traditional way, have a better quality, and arouse more trust than the conventional counterparts (mean evaluations exceeding 4.5).

On the basis of statements included in Table 7, an index on the attitudes to regional food products was created. This index is based on all positive opinions concerning regional food products from Table 6 (all except "they are more expensive"). It is an arithmetical mean of the evaluations for the 12 opinions in the 1-5 scale. The higher the index value, the more positive attitude of consumers to regional food products compared to conventional food. For regional ethnocentric consumers, this index amounted to 4.212 , whereas for the remaining study participants it was 3.677. The difference was highly statistically significant $(\mathrm{t}=13.103, \mathrm{p}<0.001)$. Unsurprisingly, regional ethnocentric consumers were characterized by a significantly more favorable attitude to regional food products compared to the rest of the sample.

The respondents were asked to select the three most important indicators on the basis of which one can assess the authenticity of regional food products (Table 8). The most important authenticity assessment criteria among regional ethnocentric consumers included natural taste, product quality, and point of sale located in the region of origin (indicated by over $30 \%$ respondents from this category). The largest differences in the importance of authenticity assessment criteria concerned the location of 
sales in the region of origin, which was much more important for regional ethnocentric consumers, and the packaging, which was more important for the remaining respondents.

Table 7. A comparison of regional ethnocentric consumers with the rest of the sample regarding their opinions on regional food products compared to the conventional food.

\begin{tabular}{ccccc}
\hline Opinions & $\mathbf{R E}$ & Other & $\mathbf{t}$ & $\mathbf{p}$ \\
\hline They are more tasty & 4.584 & 3.979 & 10.827 & $<0.001$ \\
They are produced in a more traditional way & 4.584 & 4.034 & 10.044 & $<0.001$ \\
They have a better quality & 4.533 & 3.856 & 11.963 & $<0.001$ \\
They arouse more trust & 4.506 & 3.856 & 11.689 & $<0.001$ \\
$\quad$ They are healthier & 4.467 & 3.843 & 10.429 & $<0.001$ \\
They are more authentic & 4.459 & 3.874 & 10.105 & $<0.001$ \\
I recommend their purchases to my & 4.392 & 3.699 & 10.778 & $<0.001$ \\
$\quad$ family/friends & 4.235 & 3.915 & 4.889 & $<0.001$ \\
They are more expensive & 4.188 & 3.689 & 7.898 & $<0.001$ \\
They are more environmentally friendly & 4.063 & 3.534 & 8.044 & $<0.001$ \\
They look better & 3.957 & 3.486 & 6.966 & $<0.001$ \\
They are subject to more strict controls & 3.847 & 3.403 & 6.174 & $<0.001$ \\
I accept their higher price & 2.965 & 2.877 & 1.197 & 0.232 \\
Their advertising is better &
\end{tabular}

Notes: RE-regional ethnocentric (255 respondents), Other-the rest of the sample (745 respondents); 1-5 scale.

Table 8. A comparison of regional ethnocentric consumers with the rest of the sample regarding authenticity assessment criteria for regional food products.

\begin{tabular}{cccc}
\hline Authenticity Assessment Criteria & RE & Other & Difference \\
\cline { 2 - 4 } & $\mathbf{\%}$ & $\mathbf{\%}$ & p.p. \\
\hline Natural taste & 43.5 & 41.1 & 2.4 \\
Product quality & 38.0 & 36.4 & 1.6 \\
Sale in the region of origin & 32.9 & 26.2 & 6.7 \\
Label & 27.1 & 26.8 & 0.3 \\
Point of sale-retailer type & 22.0 & 22.3 & -0.3 \\
European quality sign & 21.2 & 24.0 & -2.8 \\
Consumer knowledge & 20.4 & 20.9 & -0.5 \\
Name of the product (brand) & 19.2 & 16.6 & 2.6 \\
Low availability of such products & 18.0 & 13.0 & 5.0 \\
Look of the product & 17.3 & 18.9 & -1.6 \\
Separate exposition place in shops & 17.3 & 18.5 & -1.2 \\
Packaging & 9.8 & 16.1 & -6.3 \\
Addressing offer to tourists & 7.5 & 5.6 & 1.9 \\
Other & 0 & 0.9 & -0.9
\end{tabular}

Notes: RE-regional ethnocentric (255 respondents), Other-the rest of the sample (745 respondents); p.p.-percentage points; the sum in each column may exceed $100 \%$, because the consumers were requested to provide three criteria each.

The respondents were asked to select the three most important barriers to the development of the market of regional food products (Table 9). Regional ethnocentric consumers differed the most from the rest of the sample regarding their perception of importance of insufficient intensity of marketing activities, which they considered a much more important barrier, and of satisfaction with the consumption of conventional food, which they believed considerably less important. Generally, the most important barriers to the development of the market of regional food products according to regional ethnocentric respondents were high prices, insufficient consumer knowledge, and low availability of such products. 
Table 9. A comparison of regional ethnocentric consumers with the rest of the sample regarding the importance of barriers to the development of the market of regional food products.

\begin{tabular}{cccc}
\hline Barriers & $\mathbf{R E}$ & Other & Difference \\
\cline { 2 - 4 } & $\mathbf{\%}$ & $\mathbf{\%}$ & $\mathbf{p . p .}$ \\
High price & 51.8 & 52.6 & -0.8 \\
Insufficient consumer knowledge & 43.1 & 41.2 & 1.9 \\
Low availability & 37.6 & 32.9 & 4.7 \\
Short expiry dates & 32.5 & 28.7 & 3.8 \\
Insufficient intensity of marketing activities & 32.2 & 22.3 & 9.9 \\
Low visibility in the point of sale & 30.2 & 34.6 & -4.4 \\
Mistakes in marketing strategies & 23.5 & 19.7 & 3.8 \\
Skepticism toward the systems of certification and labelling & 21.6 & 20.7 & 0.9 \\
Satisfaction with the consumption of conventional food & 11.8 & 19.5 & -7.7 \\
Unfavorable appearance of products & 6.7 & 8.3 & -1.6 \\
Worse taste in comparison with mass products & 4.3 & 5.4 & -1.1 \\
Other & 0.4 & 0.8 & -0.4 \\
\hline
\end{tabular}

Notes: RE-regional ethnocentric (255 respondents), Other-the rest of the sample (745 respondents); p.p.- percentage points; the sum in each column may exceed $100 \%$, because the consumers were requested to provide 3 barriers each.

The respondents were asked to provide the five most important motives for selecting certain types of food. In Table 10, the results are reported for regional food and conventional food from the perspective of regional ethnocentric consumers and the rest of the sample. Regarding the selection motives for regional food products, the largest differences between regional ethnocentric respondents and the other ones were observed for price, curiosity, producer brand and reputation, richness in minerals and vitamins, and availability near one's place of living. Whereas price and curiosity are much less important for regional ethnocentric consumers than the rest of the sample, the other motives listed above are much more important for them. Generally, the most important motives for selecting regional food products by regional ethnocentric consumers comprised traditional recipe, taste, healthiness, product uniqueness, and product identification with an area of origin. As far as the selection motives for conventional food products are concerned, the largest differences between regional ethnocentric consumers and the remaining ones were noted for consumption pleasure, which was much less important according to the regional ethnocentric buyers, and advertising, which was considered a much more important selection motive in the opinion of regional ethnocentric consumers. The most important motives for selecting conventional food products indicated by regional ethnocentric consumers were price, availability near one's place of living, advertising, and expiry dates.

I was also interested whether there were any differences in the distribution channels for regional food products between regional ethnocentric consumers and the rest of the sample (Table 11). Regional ethnocentric consumers purchased regional food much more often on the producer's farm, in producer-owned shops, and during fairs, whereas the remaining respondents purchased regional food products more often in large distribution networks. These differences may suggest that regional ethnocentric consumers prefer different types of regional food products than the rest of the sample and/or they understand the term "regional food" in a different way. The differences in understanding of the concept of regional food products are discussed in the Limitations section at the end of this article. In general, regional food products were purchased most frequently by regional ethnocentric consumers in the following distribution channels: markets and bazaars, on the farm, at fairs, and in shops owned by the producer. 
Table 10. A comparison of regional ethnocentric consumers with the rest of the sample regarding food selection motives.

\begin{tabular}{ccccccc}
\hline & \multicolumn{3}{c}{ Regional Food } & \multicolumn{3}{c}{ Conventional Food } \\
\cline { 2 - 6 } Selection Motives & RE & Other & Diff. & RE & Other & Diff. \\
\cline { 2 - 6 } & $\%$ & $\%$ & p.p. & $\%$ & $\%$ & p.p. \\
\hline Traditional recipe & 47.5 & 44.0 & 3.5 & 10.2 & 10.7 & -0.5 \\
Taste & 42.7 & 44.6 & -1.9 & 27.5 & 32.2 & -4.7 \\
Healthiness & 29.8 & 29.1 & 0.7 & 9.0 & 14.0 & -5.0 \\
Product uniqueness & 29.0 & 31.9 & -2.9 & 4.7 & 6.4 & -1.7 \\
Product identification with an area of origin & 27.1 & 24.4 & 2.7 & 7.1 & 5.2 & 1.9 \\
Availability near one's place of living & 23.9 & 18.1 & 5.8 & 47.8 & 48.3 & -0.5 \\
Quality assurance (certificate, sign) & 23.1 & 19.2 & 3.9 & 11.8 & 9.5 & 2.3 \\
Consumption pleasure & 22.7 & 21.2 & 1.5 & 9.8 & 18.1 & -8.3 \\
Producer brand and reputation & 21.2 & 15.3 & 5.9 & 26.7 & 23.6 & 3.1 \\
Richness in minerals and vitamins & 20.4 & 14.5 & 5.9 & 7.1 & 6.7 & 0.4 \\
Smell & 20.4 & 17.7 & 2.7 & 12.9 & 14.2 & -1.3 \\
Ecological character of the product & 18.0 & 14.1 & 3.9 & 6.7 & 6.6 & 0.1 \\
Food safety & 16.5 & 14.2 & 2.3 & 13.7 & 12.5 & 1.2 \\
Concern for local producers & 16.1 & 14.2 & 1.9 & 4.7 & 7.4 & -2.7 \\
Brand and reputation of the point of sale & 16.1 & 11.8 & 4.3 & 17.3 & 18.3 & -1.0 \\
Opinions of family/friends & 15.3 & 15.6 & -0.3 & 22.4 & 21.6 & 0.8 \\
Curiosity & 13.7 & 19.6 & -5.9 & 14.5 & 10.3 & 4.2 \\
Price & 12.5 & 22.1 & -9.6 & 67.5 & 68.1 & -0.6 \\
Loyalty & 10.2 & 9.0 & 1.2 & 6.7 & 7.7 & -1.0
\end{tabular}

Notes: RE-regional ethnocentric (255 respondents), Other-the rest of the sample (745 respondents); Diff.-Difference; p.p.-percentage points; the sum in each column may exceed $100 \%$, because the consumers were requested to provide 5 motives each.

Table 11. A comparison of regional ethnocentric consumers with the rest of the sample regarding the distribution channels used for regional food products.

\begin{tabular}{cccc}
\hline \multirow{2}{*}{ Distribution Channels } & RE & Other & Difference \\
\cline { 2 - 4 } & $\mathbf{\%}$ & $\mathbf{\%}$ & p.p. \\
\hline Markets, bazaars & 51.4 & 48.5 & 2.9 \\
On the farm & 38.8 & 23.9 & 14.9 \\
Fairs & 35.7 & 27.4 & 8.3 \\
Producer-owned shops & 34.5 & 24.3 & 10.2 \\
Festivals & 28.2 & 23.6 & 4.6 \\
Independent groceries & 21.6 & 16.5 & 5.1 \\
Specialized organic shops & 19.2 & 15.6 & 3.6 \\
Large distribution networks & 16.9 & 24.8 & -7.9 \\
Internet & 8.2 & 5.2 & 3.0 \\
Restaurants & 5.1 & 8.3 & -3.2 \\
Other & 0.8 & 0 & 0.8
\end{tabular}

Notes: RE-regional ethnocentric (255 respondents), Other-the rest of the sample (745 respondents); p.p.--percentage points; the sum in each column may exceed $100 \%$, because it was a multiple-choice question.

Moreover, it was found out that regional ethnocentric consumers purchased regional food products as a tourist significantly more often than the rest of the sample $(3.961$ vs. $3.250, t=8.344, p<0.001)$.

Variables for which significant differences were observed between consumers with a high level of regional ethnocentrism and the rest of the sample were tested in a series of simple regressions in which 
the dependent variable was the importance attached to regional food products originating from the region where the respondent lived, measured in a five-point scale (very high, rather high, average, rather low, with no importance). Unsurprisingly, regional ethnocentrism is related to the share of regional products in one's food purchases $\left(\beta=0.242, \mathrm{SE}=0.032, \mathrm{t}=7.669, \mathrm{p}<0.001, \mathrm{R}^{2}=0.059\right)$ and the willingness to pay a higher price for regional products compared to conventional food $(\beta=0.171$, $\left.\mathrm{SE}=0.031, \mathrm{t}=5.480, \mathrm{p}<0.001, \mathrm{R}^{2}=0.029\right)$. It is strongly affected by national ethnocentrism both on the market of conventional food $\left(\beta=0.443, \mathrm{SE}=0.028, \mathrm{t}=15.602, \mathrm{p}<0.001, \mathrm{R}^{2}=0.196\right)$ and regional food products $\left(\beta=0.560, \mathrm{SE}=0.026, \mathrm{t}=21.378, \mathrm{p}<0.001, \mathrm{R}^{2}=0.314\right)$. The importance attached to the following characteristics of food products turned out to exert a statistically significant impact on the regional ethnocentrism: area of origin $\left(\beta=0.326, \mathrm{SE}=0.030, \mathrm{t}=10.884, \mathrm{p}<0.001, \mathrm{R}^{2}=0.106\right)$, quality signs $\left(\beta=0.311, \mathrm{SE}=0.030, \mathrm{t}=10.345, \mathrm{p}<0.001, \mathrm{R}^{2}=0.097\right)$, brand $(\beta=0.249, \mathrm{SE}=0.031, \mathrm{t}=8.129, \mathrm{p}$ $\left.<0.001, \mathrm{R}^{2}=0.062\right)$, trusting the point of sale (retailer) $\left(\beta=0.269, \mathrm{SE}=0.030, \mathrm{t}=8.808, \mathrm{p}<0.001, \mathrm{R}^{2}=\right.$ $0.072)$, and product appearance $\left(\beta=0.188, \mathrm{SE}=0.031, \mathrm{t}=6.043, \mathrm{p}<0.001, \mathrm{R}^{2}=0.035\right)$.

As far as consumers' opinions about regional food products in comparison with conventional food are concerned, the following statements reached statistical significance: they have a higher quality $\left(\beta=0.394, \mathrm{SE}=0.029, \mathrm{t}=13.556, \mathrm{p}<0.001, \mathrm{R}^{2}=0.156\right)$, they have a higher price $(\beta=0.120, \mathrm{SE}=$ $\left.0.031, \mathrm{t}=3.813, \mathrm{p}<0.001, \mathrm{R}^{2}=0.014\right)$, they are more authentic $(\beta=0.373, \mathrm{SE}=0.029, \mathrm{t}=12.715, \mathrm{p}<$ $\left.0.001, R^{2}=0.139\right)$, they are more tasty $\left(\beta=0.387, S E=0.029, t=13.278, p<0.001, R^{2}=0.150\right)$, they are produced in a more traditional way $\left(\beta=0.316, \mathrm{SE}=0.030, \mathrm{t}=10.524, \mathrm{p}<0.001, \mathrm{R}^{2}=0.100\right)$, they are more environmentally friendly $\left(\beta=0.296, \mathrm{SE}=0.030, \mathrm{t}=9.784, \mathrm{p}<0.001, \mathrm{R}^{2}=0.088\right)$, they are subject to a stricter control $\left(\beta=0.251, \mathrm{SE}=0.031, \mathrm{t}=8.179, \mathrm{p}<0.001, \mathrm{R}^{2}=0.063\right)$, they are healthier $(\beta=0.344$, $\left.\mathrm{SE}=0.030, \mathrm{t}=11.588, \mathrm{p}<0.001, \mathrm{R}^{2}=0.119\right)$, they arouse more trust $(\beta=0.401, \mathrm{SE}=0.029, \mathrm{t}=13.830, \mathrm{p}$ $\left.<0.001, R^{2}=0.161\right)$, they look better $\left(\beta=0.293, S E=0.030, t=9.679, p<0.001, R^{2}=0.086\right)$, I accept their higher price $\left(\beta=0.278, \mathrm{SE}=0.030, \mathrm{t}=9.126, \mathrm{p}<0.001, \mathrm{R}^{2}=0.077\right)$, and I recommend purchasing them to my family / friends $\left(\beta=0.420, \mathrm{SE}=0.029, \mathrm{t}=14.614, \mathrm{p}<0.001, \mathrm{R}^{2}=0.176\right.$ ). Regional ethnocentrism also depended (negatively) on considering packaging as a criterion for assessing the authenticity of regional food products $\left(\beta=-0.077, \mathrm{SE}=0.032, \mathrm{t}=-2.431, \mathrm{p}=0.015, \mathrm{R}^{2}=0.006\right)$. It was related to treating insufficiently intensive marketing activities as a barrier to the development of regional food products $\left(\beta=0.109, \mathrm{SE}=0.031, \mathrm{t}=3.456, \mathrm{p}<0.001, \mathrm{R}^{2}=0.012\right)$. Regarding the motives for choosing regional food, curiosity $\left(\beta=-0.129, \mathrm{SE}=0.031, \mathrm{t}=-4.114, \mathrm{p}<0.001, \mathrm{R}^{2}=0.017\right)$ and price $(\beta=$ $\left.-0.105, \mathrm{SE}=0.031, \mathrm{t}=-3.345, \mathrm{p}<0.001, \mathrm{R}^{2}=0.011\right)$ reduced regional ethnocentrism, while richness in minerals and vitamins increased it $\left(\beta=0.079, \mathrm{SE}=0.032, \mathrm{t}=2,506, \mathrm{p}=0.012, \mathrm{R}^{2}=0.006\right)$. Regional ethnocentrism was also influenced by motives of conventional food selection, namely consumption pleasure (inverse relationship: $\beta=-0.072, \mathrm{SE}=0.032, \mathrm{t}=-2.294, \mathrm{p}=0.022, \mathrm{R}^{2}=0.005$ ) and advertising $\left(\beta=0.079, \mathrm{SE}=0.032, \mathrm{t}=2.493, \mathrm{p}=0.013, \mathrm{R}^{2}=0.006\right)$. The level of regional ethnocentrism was related to the preferences of distribution channels for regional food. Buying such products directly on the farm $\left(\beta=0.148, \mathrm{SE}=0.031, \mathrm{t}=4.715, \mathrm{p}<0.001, \mathrm{R}^{2}=0.022\right)$, in shops belonging to the producer $(\beta=$ $\left.0.193, \mathrm{SE}=0.031, \mathrm{t}=6.208, \mathrm{p}<0.001, \mathrm{R}^{2}=0.037\right)$, and during fairs attended by producers $(\beta=0.096$, $\left.\mathrm{SE}=0.032, \mathrm{t}=3.041, \mathrm{p}=0.002, \mathrm{R}^{2}=0.009\right)$ increases regional ethnocentrism, while purchasing regional food in large distribution networks (hypermarkets, supermarkets, discount stores etc.) reduces it ( $\beta=$ $\left.-0.082, \mathrm{SE}=0.032, \mathrm{t}=-2.604, \mathrm{p}=0.009, \mathrm{R}^{2}=0.007\right)$. Finally, the frequency of purchasing regional food products as a tourist has a positive impact on the regional ethnocentrism $(\beta=0.335, \mathrm{SE}=0.030, \mathrm{t}=$ 11.216, $\mathrm{p}<0.001, \mathrm{R}^{2}=0.112$ ).

Those independent variables that turned out statistically significant at the level of $\mathrm{p}<0.05$ in simple regressions were included in a multiple regression model. For the sake of parsimony, only those variables that remained significant are included in the final version of the multiple regression model (Table 12). The model explains $46 \%$ of the variance and is significant at the level of $\mathrm{p}<0.0001$. According to the multiple regression results, the strongest predictors of regional ethnocentrism are national ethnocentrism and importance attached to quality signs in regional food purchases $(\beta>0.3)$. Regional ethnocentrism is also strengthened by the importance of brand and retailer trust as food 
product characteristics, indicating insufficient marketing as one of the most important barriers to the development of the market of regional food, purchasing regional food products in shops belonging to the producer, and as a tourist. Regional ethnocentrism is reduced by purchasing regional food products in large distribution networks, such as hypermarkets, supermarkets, or discount stores.

Table 12. Selected predictors of regional ethnocentrism on the food market (a multiple regression model).

\begin{tabular}{ccccc}
\hline Independent Variables & $\boldsymbol{\beta}$ & $\mathbf{S E}$ & $\mathbf{t}$ & $\mathbf{p}$ \\
\hline Intercept & $\mathrm{x}$ & $\mathrm{x}$ & -0.076 & 0.939 \\
Brand (a) & 0.064 & 0.026 & 2.454 & 0.014 \\
Retailer trust (b) & 0.054 & 0.026 & 2.057 & 0.040 \\
Quality signs (c) & 0.308 & 0.028 & 11.125 & $<0.001$ \\
Marketing intensiveness (d) & 0.057 & 0.024 & 2.436 & 0.015 \\
Producer shops (e) & 0.075 & 0.024 & 3.137 & 0.002 \\
Large distribution networks (f) & -0.077 & 0.023 & -3.293 & 0.001 \\
National ethnocentrism (g) & 0.357 & 0.027 & 13.205 & $<0.001$ \\
Tourist purchases (h) & 0.105 & 0.025 & 4.145 & $<0.001$ \\
\hline
\end{tabular}

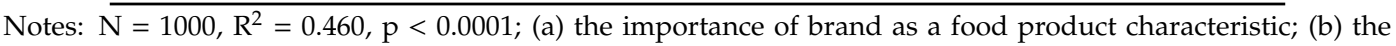
importance of trusting the retailer as a food product characteristic; (c) the importance of quality signs in regional food purchases; (d) indicating insufficiently intensive marketing activities as one of three most important barriers to the development of the market of regional food products; (e) purchasing regional food products in shops belonging to the producer; (f) purchasing regional food products in large distribution networks; (g) the importance of a regional food product originating from Poland; (h) purchasing regional food products as a tourist.

Furthermore, the impact of regional ethnocentrism on declared consumer behavior was observed, regarding the share of products originating from the consumer's region in the purchases of regional food $\left(\beta=0.309, \mathrm{SE}=0.031, \mathrm{t}=9.975, \mathrm{p}<0.001, \mathrm{R}^{2}=0.096\right)$. This congruence between the attitudinal and behavioral measures of regional ethnocentrism needs to be emphasized, as it reinforces the managerial implications of my findings, even though both variables were self-reported rather than observed.

\section{Discussion}

I conceptualized regional ethnocentrism as the importance attached to products originating from one's own region rather than the preference for any regional products. This approach is close to definitions of local food, the consumption of which contributes to the sustainable development of regions. Now, I am going to discuss possible connections of the regional ethnocentrism predictors identified in this study with the principal dimensions of the sustainable development concept. The popularity of "sustainability" stems from a simple model used to facilitate the comprehension of the term: the triangle of environmental (conservation), economic (growth), and social (equity) dimensions. Sustainable development is often modeled on these three pillars [45]. Sometimes, a fourth dimension of sustainable development is added to the model, namely the institutional pillar, also referred to as "democracy" or "governance" [46]. I will refer to selected results of both simple and multiple regressions reported above. Regarding the economic dimension, it is worth noting such predictors as attaching high importance to food brands and quality signs, indicating insufficient marketing as a barrier to the development of the market of regional food, accepting higher prices of regional food products, higher willingness to pay, assessing regional products as more authentic than conventional food, and purchasing them directly on the farm or in shops belonging to the producer. Economic sustainability is best secured by the creation of local or regional self-reliant, community economies [47], to which regional ethnocentrism contributes. These factors contribute to higher incomes of local farmers, processors and distributors. National ethnocentrism may also be included in this dimension due to the support for the national economy. As far as the social dimension is concerned, one may mention trust in regional products and in their points of sale (retailers), traditional way of production, purchasing regional food during fairs attended by manufacturers and recommending regional food to one's family and friends. These factors strengthen the embeddedness of supply chains in local 
communities. Purchasing regional products as a tourist may be added to the social dimension, as it forms a part of the tourist experience in another country or region. Regarding the ecological dimension, it is worth emphasizing the conviction that regional products are more environmentally friendly than conventional food, are healthier, and are subject to stricter controls. Moreover, preferring products from one's own region means lower distances in transporting the products from producers to consumers, which usually means lower pollution and energy conservation. Transport (or distance between production and consumption) is an important factor in determining the environmental sustainability of food supply chains [48]. However, there is a strong danger of oversimplification when using food miles as a sustainability assessment tool. The food miles concept can be enhanced with all relevant transport externalities taking into account different transport modes and transport (in)efficiency [49]. To overcome the cost disadvantages brought about by its small-scale production and high delivery costs, locally sourced food should add some extra value, which in this case is related to regional ethnocentrism. Short supply chains have advantages over long ones, but they are not sustainable per se [50]. A European study of 14 local and global food products demonstrated that the sustainability strength of local and intermediary products was mainly in health and socio-economic dimensions, particularly aspects of care and links to the territory such as biodiversity, animal welfare, governance, or resilience, whereas global food products presented substantial advantages in terms of climate change mitigation and affordability to consumers, which contrasts with the food-miles ecological claim. Distance is not the most critical factor in improving sustainability of food products, and other criteria of localness (identity, governance, or size) play a more critical role [51].

It is worth comparing some of my results in the segment of regional ethnocentric consumers with the general perceptions of organic food in Poland [52]. As far as the authenticity assessment criteria are concerned, Polish consumers indicated natural taste and product quality as the most important ones also for organic food. The third criterion differs: among regional ethnocentric consumers evaluating origin food, it was sale in the region of origin, whereas for organic food, it was the label according to the whole sample. Perhaps, an explanation may be that the organic farming logo is better recognized than the quality signs for regional products (PDO-Protected Designation of Origin, and PGI-Protected Geographical Indication). Regarding the barriers to the development of the organic food market, the first four were exactly the same as for the regional food market as perceived by regional ethnocentric buyers. Only the fifth one differed. It was weak merchandising for organic products in the total sample, and insufficient intensity of marketing activities for regional food in the opinion of the ethnocentric respondents. The last comparison will concern food selection motives. In this case, the differences between the opinion of regional ethnocentric consumers concerning regional food and the opinions of the total sample regarding organic food were the most pronounced. The former selected traditional recipe, taste, healthiness, product uniqueness, and product identification with an area of origin as the most important, whereas the latter emphasized the role of healthiness, the ecological character of products, food safety, taste, and quality assurance. In spite of these differences, I may conclude that there are considerable similarities in the perception of organic food in Poland and regional food from the perspective of regional ethnocentric buyers.

\section{Conclusions}

Regional products are a diverse category, including products originating from one's own region, but also products coming from other regions with an appeal to the area of origin. Preferring regional products from one's own region may be considered a sign of regional ethnocentrism. In this study, I identified a number of predictors of this attitude. In a multiple regression model, it depends on the importance of brand and retailer trust on the food market, the importance of quality signs in regional food purchases, opinion that insufficient marketing constitutes an important barrier to the development of the regional food market, buying regional products in shops owned by producers rather than large distribution networks, frequency of purchasing regional products as a tourist, and last but not least, attaching high importance to the national origin of regional products (national ethnocentrism). I argue 
that regional ethnocentrism may be considered a pattern of sustainable consumption, as its predictors are strongly related to the major pillars of sustainable development.

\subsection{Theoretical Implications}

This paper contributes to the theory of consumer ethnocentrism by providing more insights about its regional dimension in the context of the market of regional food products. These results indicate that demographic and socioeconomic criteria have limited power in explaining this phenomenon. It was found that regional ethnocentric consumers attach higher importance (compared to the rest of the sample) to certain characteristics of food products (in general, not only regional food), especially quality signs, area of origin, and trust in the point of sale (retailer), but also brand, product appearance, and price. Quality signs are more important for regional ethnocentric consumers. Interestingly, this applied not only to regional food, but also conventional food. Regional ethnocentric consumers are also characterized by strong classical (national) ethnocentrism both on the market of regional food and conventional food. Therefore, regional and national ethnocentrisms are strongly correlated, although these are distinct concepts. Furthermore, regional ethnocentrism is associated with the favorable attitude to all kinds of regional food products, regardless of their region of origin. Regional ethnocentric consumers differ from the remainder of buyers in the way they assess the authenticity of regional food, as they pay more attention to the location of sales in the same region from which the product originates, and are less inclined to assess the authenticity on the basis of the product packaging. Regional ethnocentric consumers have different perceptions about the importance of barriers to the development of the regional food market than other consumer segments. In particular, they emphasize the role of insufficient intensity of marketing activities on this market and diminish the role of satisfaction with the consumption of substitutes from the conventional food category. Regional ethnocentric consumers are characterized by different food selection motives than other buyers both for regional food and for conventional food. Regarding regional products, they are motivated less by the price, whereas in conventional food purchases, they underline the importance of advertising and are driven less by the consumption pleasure. Regional ethnocentric consumers also differ in their preferences for distribution channels. They tend to buy regional food much more often in direct channels, such as on the farm or in producer-owned shops. In the touristic context, they buy regional food products more often than the rest of respondents.

A multiple regression model identified the following predictors of regional ethnocentrism on the food market: (a) the importance of brand as a food product characteristic, (b) the importance of trusting the retailer as a food product characteristic, (c) the importance of quality signs in regional food purchases, (d) indicating insufficiently intensive marketing activities as one of three most important barriers to the development of the market of regional food products, (e) purchasing regional food products in shops belonging to the producer, (f) purchasing regional food products in large distribution networks, $(\mathrm{g})$ the importance of a regional food product originating from Poland, and $(\mathrm{h})$ purchasing regional food products as a tourist. All of them contribute positively to regional ethnocentrism, with the notable exception of buying regional food in big distribution networks. The strongest predictors are national ethnocentrism and the importance attached to quality signs. The predictors of regional ethnocentrism can be analyzed through the lens of sustainable development pillars. They are largely congruent with this framework, which is why I argue that regional ethnocentrism may be considered a pattern of sustainable consumption.

\subsection{Managerial Implications}

These results confirm the existence of an important segment of food consumers who attach very high importance to the origin of the products. Unlike most research studies that focus on the country of origin effect, I studied the importance attached to the origin of the product from the same region as the consumer. This segment of the regional ethnocentric consumers amounted to $13.4 \%$ of buyers of conventional (mass) food, $17.4 \%$ among organic food consumers, and over a quarter $(25.5 \%)$ 
of regional food buyers. Therefore, emphasizing the local origin of the product in the marketing communication may appeal as a primary or secondary attribute to a considerable segment of consumers. This preference for products originating from one's own region is not limited to regional products (i.e., by definition referring to their region of origin), but also-albeit to a lower extent-to organic food and even conventional food. Moreover, this segment is managerially attractive, because it is characterized by a higher willingness to pay for regional products ( $19.5 \%$ vs $16.0 \%$ for the rest of the sample) as well as a higher share of regional products in total food purchases (38.3\% compared to $27.3 \%$ ). As regional products tend to be more expensive than their conventional counterparts, the value of this segment should not be underestimated.

Second, as regional ethnocentric consumers are driven by quality signs to a larger extent than other segments, it is advisable to apply for such labels (e.g., PDO, PGI) and use them intensively in the marketing communication for regional food.

Third, my results suggest that regional ethnocentrism is highly correlated with national ethnocentrism (i.e., preferring products from one's own country). Therefore, it is recommended not only to emphasize the local region of origin, but at the same time communicate the national origin of the product e.g., through special labels (e.g., "Kupuje polskie produkty"-_I buy Polish products"), symbols (e.g., the national flag), colors (the same as on the national flag), or merchandising (special displays of national products).

Fourth, as regional ethnocentric consumers assess the authenticity of regional food products to a larger extent than the rest of buyers through locating the sale of the product in the region of origin (a difference of 6.7 percentage points) and low availability of such products (a difference of 5.0 percentage points), it is recommended to develop local, exclusive distribution networks for such products, whereas large, national, or international distribution networks should pay attention to customize the assortment to the local needs by offering products originating from a given region.

Fifth, as regional ethnocentric consumers perceive insufficient intensity of marketing activities as an important barrier to the development of the market of regional food products (a difference of 9.9 percentage points compared to the rest of the sample), it is advisable to intensify such efforts, including in new types of marketing communication channels, e.g., social media and mobile applications. Cooperation with opinion leaders (influencers), e.g., culinary bloggers, would be welcomed.

Sixth, since regional ethnocentric consumers are driven by the price motive to a lesser extent than other segments (9.6 percentage points difference) in their choice of regional food, it is recommended to develop local brands positioned in various price ranges, including premium and super-premium pricing.

Seventh, as regional ethnocentric consumers buy regional food more often on the farm and in producer-owned shops in comparison with other respondents (respective differences of 14.9 and 10.2 percentage points), facilitating the development of short supply chains and direct distribution of such products is recommended. Horizontal and vertical market channel integration seems crucial in this area.

\subsection{Limitations}

All the variables included in this study are self-reported rather than observed. Due to potential attitude-behavior gap, which is common in consumer studies, the results should be treated with caution. However, this bias was minimized by the data collection technique that was used. As the survey was administered anonymously on an online platform, the respondents were less affected by social desirability than in face-to-face interviews. All the same, some answers could be inaccurate for other reasons, e.g., memory limitations. The choice of the research method was driven by cost-benefit considerations in the context of the study objectives.

The concept of regional food products was not defined at the beginning of the survey questionnaire. The respondents could understand it in various ways, which is a limitation of this study. The most obvious understanding of regional products refers to products for which the region of origin in emphasized. However, some consumers could limit this category only to local products or-probably 
less often-to products having special quality signs for regional food (especially PDO and PGI). Nevertheless, the wording of particular questions in the survey limited the potential bias stemming from these differences in understanding of the concept of regional products, as the respondents were asked directly what share of regional products they bought constituted products originating from their own region and how important the origin of the regional product from the region where they lived was for them. Therefore, they were made aware that regional products may also come from other regions than their own. As the survey was done on an online platform, the respondents were free to return to previous questions if they realized that their answers were based on an incorrect understanding of the concept of regional food. This contributed to reduce the potential bias but did not eliminate it completely.

Similarly, the respondents were free to interpret the terms of organic and "ordinary" (conventional) food on their own. The term "organic" could be understood as having an organic food certificate/logo, but some respondents could approach this term more broadly, focusing on the method of production itself rather than a formal recognition of it. The term "conventional" was not used in the survey, as it would have been less understood than "ordinary" or "mass" food (at least in the Polish language, in which the survey was conducted). However, it is used in the description of results, as it is widely accepted in the literature of the subject concerning the comparisons with organic food [53], PDO/PGI-labeled products [54], local food [55], origin food [44], alternative food [56], and regional food [57].

Another limitation is related to not including respondents at the age of over 65 . This was due to the structure of the research agency online panel.

\subsection{Future Research Directions}

The study may be replicated with the use of a survey explaining the concepts of regional and organic products to the respondents rather than relying on their own interpretations of these terms. Future research may investigate the phenomenon of regional ethnocentrism in other country settings and for other product and service categories. The phenomenon of regional ethnocentrism may be studied in experimental settings with the use of real or fictitious brands associated with different regions. The role of textual appeals to the region of origin on the product packaging may be compared to visual stimuli having the same objective, such as logos, pictures, maps, or symbols. Eye-tracking may be used to study to attention paid to the region-or-origin information on the packaging.

Funding: This research was funded by the Polish Ministry of Science and Higher Education, Iuventus Plus research grant number IP 2011 004371, and the National Science Centre, Opus grant number 2017/25/B/HS4/00031. The APC was funded by the National Science Centre, Opus grant number 2017/25/B/HS4/00031.

Conflicts of Interest: The author declares no conflict of interest. The funders had no role in the design of the study; in the collection, analyses, or interpretation of data; in the writing of the manuscript, or in the decision to publish the results.

\section{References}

1. Wang, C.; Ghadimi, P.; Lim, M.; Tseng, M. A literature review of sustainable consumption and production: A comparative analysis in developed and developing economies. J. Clean. Prod. 2019, 206, 741-754. [CrossRef]

2. Akenji, L.; Bengtsson, M. Making sustainable consumption and production the core of sustainable development goals. Sustainability 2014, 6, 513-529. [CrossRef]

3. Bengtsson, M.; Alfredsson, E.; Cohen, M.; Lorek, S.; Schroeder, P. Transforming systems of consumption and production for achieving the sustainable development goals: Moving beyond efficiency. Sustain. Sci. 2018, 13, 1533-1547. [CrossRef] [PubMed]

4. Minton, E.; Spielmann, N.; Kahle, L.; Kim, C. The subjective norms of sustainable consumption: A cross-cultural exploration. J. Bus. Res. 2018, 82, 400-408. [CrossRef]

5. Young, W.; Hwang, K.; McDonald, S.; Oates, C. Sustainable consumption: Green consumer behaviour when purchasing products. Sustain. Dev. 2010, 18, 20-31. [CrossRef] 
6. Scott, A.; Oates, C.; Young, W. A conceptual framework of the adoption and practice of environmental actions in households. Sustainability 2015, 7, 5793-5818. [CrossRef]

7. Vermeir, I.; Verbeke, W. Sustainable food consumption: Exploring the consumer "attitude-behavioral intention" gap. J. Agric. Environ. Ethics 2006, 19, 169-194. [CrossRef]

8. Brach, S.; Walsh, G.; Shaw, D. Sustainable consumption and third-party certification labels: Consumers' perceptions and reactions. Eur. Manag. J. 2018, 36, 254-265. [CrossRef]

9. Onel, N.; Mukherjee, A.; Kreidler, N.; Díaz, E.; Furchheim, P.; Gupta, S.; Keech, J.; Murdock, M.; Wang, Q. Tell me your story and I will tell you who you are: Persona perspective in sustainable consumption. Psychol. Mark. 2018, 35, 752-765. [CrossRef]

10. Morone, P.; Falcone, P.; Lopolito, A. How to promote a new and sustainable food consumption model: A fuzzy cognitive map study. J. Clean. Prod. 2019, 208, 563-574. [CrossRef]

11. Bryła, P. The development of organic food market as an element of sustainable development implementation. Probl. Sustain. Dev. 2015, 10, 79-88.

12. Oroian, C.; Safirescu, C.; Harun, R.; Chiciudean, G.; Arion, F.; Muresan, I.; Bordeanu, B. Consumers' attitudes towards organic products and sustainable development: A case study of Romania. Sustainability 2017, 9, 1559. [CrossRef]

13. Torres-Ruiz, F.; Vega-Zamora, M.; Parras-Rosa, M. Sustainable consumption: Proposal of a multistage model to analyse consumer behaviour for organic foods. Bus. Strategy Environ. 2018, 27, 588-602. [CrossRef]

14. Annunziata, A.; Agovino, M.; Mariani, A. Sustainability of Italian families' food practices: Mediterranean diet adherence combined with organic and local food consumption. J. Clean. Prod. 2019, 206, 86-96. [CrossRef]

15. Seyfang, G. Ecological citizenship and sustainable consumption: Examining local organic food networks. J. Rural Stud. 2006, 22, 383-395. [CrossRef]

16. Giampietri, E.; Koemle, D.; Yu, X.; Finco, A. Consumers' sense of farmers' markets: Tasting sustainability or just purchasing food? Sustainability 2016, 8, 1157. [CrossRef]

17. De Bernardi, P.; Tirabeni, L. Alternative food networks: Sustainable business models for anti-consumption food cultures. Br. Food J. 2018, 120, 1776-1791. [CrossRef]

18. Lee, M.; Fernandez, K.; Hyman, M. Anti-consumption: An overview and research agenda. J. Bus. Res. 2009, 62, 145-147. [CrossRef]

19. Brons, A.; Oosterveer, P. Making sense of sustainability: A practice theories approach to buying food. Sustainability 2017, 9, 467. [CrossRef]

20. Shankarmahesh, M. Consumer ethnocentrism: An integrative review of its antecedents and consequences. Int. Mark. Rev. 2006, 23, 146-172. [CrossRef]

21. Siamagka, N.; Balabanis, G. Revisiting consumer ethnocentrism: Review, reconceptualization, and empirical testing. J. Int. Mark. 2015, 23, 66-86. [CrossRef]

22. Fernández-Ferrín, P.; Bande-Vilela, B. Regional ethnocentrism: Antecedents, consequences, and moderating effects. Food Qual. Prefer. 2013, 30, 299-308. [CrossRef]

23. Van Ittersum, K.; Candel, M.; Meulenberg, M. The influence of the image of a product's region of origin on product evaluation. J. Bus. Res. 2003, 56, 215-226. [CrossRef]

24. Printezis, I.; Grebitus, C. Marketing channels for local food. Ecol. Econ. 2018, 152, 161-171. [CrossRef]

25. Meyerding, S.; Trajer, N.; Lehberger, M. What is local food? The case of consumer preferences for local food labelling of tomatoes in Germany. J. Clean. Prod. 2019, 207, 30-43. [CrossRef]

26. Kumar, A.; Smith, S. Understanding local food consumers: Theory of planned behavior and segmentation approach. J. Food Prod. Mark. 2018, 24, 196-215. [CrossRef]

27. Morgan, E.; Severs, M.; Hanson, K.; McGuirt, J.; Becot, F.; Wang, W.; Kolodinsky, J.; Sitaker, M.; Pitts, S.; Ammerman, A.; et al. Gaining and maintaining a competitive edge: Evidence from CSA members and farmers on local food marketing strategies. Sustainability 2018, 10, 2177. [CrossRef]

28. Siemieniako, D.; Kubacki, K.; Glińska, E.; Krot, K. National and regional ethnocentrism: A case study of beer consumers in Poland. Br. Food J. 2011, 133, 404-418. [CrossRef]

29. Van Ittersum, K.; Meulenberg, M.; Van Tijp, H.; Candel, M. Consumers' appreciation of regional certification labels: A Pan-European study. J. Agric. Econ. 2007, 58, 1-23. [CrossRef]

30. Bryła, P. The impact of obtaining a European quality sign on origin food producers. Qual. Assur. Saf. Crop. Foods 2018, 10, 155-164. [CrossRef] 
31. Bryła, P. The perception of EU quality signs for origin and organic food products among Polish consumers. Qual. Assur. Saf. Crop. Foods 2017, 9, 345-355. [CrossRef]

32. Fernández-Ferrín, P.; Calvo-Turrientes, A.; Bande, B.; Artaraz-Minón, M.; Galán-Ladero, M. The valuation and purchase of food products that combine local, regional and traditional features: The influence of consumer ethnocentrism. Food Qual. Prefer. 2018, 64, 138-147. [CrossRef]

33. García-Gallego, J.; Chamorro Mera, A. COO vs. ROO: Importance of the origin in customer preferences towards financial entities. Int. Mark. Rev. 2017, 34, 206-223. [CrossRef]

34. García-Gallego, J.; Chamorro Mera, A. The region-of-origin effect in the choice of banks. Int. J. Bank Mark. 2018, 36, 1367-1385. [CrossRef]

35. Fernández-Ferrín, P.; Bande, B.; Galán-Ladero, M. Parental influence on the levels of regional ethnocentrism of youth: An exploratory analysis. Span. J. Mark. 2017, 21, 52-62. [CrossRef]

36. Bryła, P. Consumer ethnocentrism on the organic food market in Poland. Mark. Zarzadzanie 2017, 2, 11-20. [CrossRef]

37. Seidenfuss, K.; Kathawala, Y.; Dinnie, K. Regional and country ethnocentrism: Broadening ASEAN origin perspectives. Asia Pac. J. Mark. Logist. 2013, 25, 298-320. [CrossRef]

38. Domański, T.; Bryła, P. Marketing Produktów Regionalnych na Europejskim Rynku Żywności; Lodz University Press: Lodz, Poland, 2013; pp. 44-81.

39. Ozimek, I.; Żakowska-Biemans, S.; Gutkowska, K. Polish consumers' perception of food-related risks. Pol. J. Food Nutr. Sci. 2009, 59, 189-192.

40. Jeżewska-Zychowicz, M.; Jeznach, M.; Kosicka-Gębska, M. Consumers' interests in sweets with health-promoting properties and their selected determinants. Pol. J. Food Nutr. Sci. 2013, 63, 43-47. [CrossRef]

41. Bryła, P. Marketing Regionalnych i Ekologicznych Produktów Żywnościowych. Perspektywa Sprzedawcy i Konsumenta; Lodz University Press: Lodz, Poland, 2015; pp. 287-354.

42. Van Ittersum, K.; Candel, M.; Torelli, F. The market for PDO/PGI protected regional products: Consumers' attitudes and behaviour. In The Socio-Economics of Origin Labeled Products in Agri-Food Supply Chains: Spatial, Institutional and Co-Ordination Aspects; Sylvander, B., Barjolle, D., Arfini, F., Eds.; INRA: Paris, France, 2000; Volume 1, pp. 215-221.

43. Central Statistical Office. The Statistical Yearbook of the Republic of Poland; Central Statistical Office: Warsaw, Poland, 2013.

44. Bryła, P. The role of appeals to tradition in origin food marketing: A survey among Polish consumers. Appetite 2015, 91, 302-310. [CrossRef]

45. Keiner, M. History, Definition(s) and Models of Sustainable Development. ETH Zürich. Available online: https://doi.org/10.3929/ethz-a-004995678 (accessed on 4 September 2019).

46. Waas, T.; Hugé, J.; Verbruggen, A.; Wright, T. Sustainable development: A bird's eye view. Sustainability 2011, 3, 1637-1661. [CrossRef]

47. Curtis, F. Eco-localism and sustainability. Ecol. Econ. 2003, 46, 83-102. [CrossRef]

48. Sim, S.; Barry, M.; Clift, R.; Cowell, S. The relative importance of transport in determining an appropriate sustainability strategy for food sourcing. Int. J. Life Cycle Assess. 2007, 12, 422.

49. Van Passel, S. Food miles to assess sustainability: A revision. Sustain. Dev. 2013, 21, 1-17. [CrossRef]

50. Lehtinen, U. Sustainability and local food procurement: A case study of Finnish public catering. Br. Food J. 2012, 114, 1053-1071. [CrossRef]

51. Schmitt, E.; Galli, F.; Menozzi, D.; Maye, D.; Touzard, J.-M.; Marescotti, A.; Six, J.; Brunori, G. Comparing the sustainability of local and global food products in Europe. J. Clean. Prod. 2017, 165, 346-359. [CrossRef]

52. Bryła, P. Organic food consumption in Poland: Motives and barriers. Appetite 2016, 105, 737-746. [CrossRef]

53. Stolz, H.; Stolze, M.; Hamm, U.; Janssen, M.; Ruto, E. Consumer attitudes towards organic versus conventional food with specific quality attributes. NJAS Wagening. J. Life Sci. 2011, 58, 67-72. [CrossRef]

54. Kos Skubic, M.; Erjavec, K.; Ule, A.; Klopčič, M. Consumers' hedonic liking of different labeled and conventional products in Slovenia. J. Sens. Stud. 2018, 33, e12444. [CrossRef]

55. Rossi, J.; Johnson, T.; Hendrickson, M. The economic impacts of local and conventional food sales. J. Agric. Appl. Econ. 2017, 49, 555-570. [CrossRef] 
56. Schrager, B. Different conceptions of place: Alternative food networks and everyday meals. Geoforum 2018, 95, 21-24. [CrossRef]

57. Franz, R.; Enneking, U.; Balling, R. Perceived safety of organic and regional food from a perspective of uncertain consumers. In Quality Management in Food Chains; Theuvsen, L., Spiller, A., Peupert, M., Jahn, G., Eds.; Wageningen Academic Publishers: Wageningen, The Netherlands, 2007; pp. 255-264.

(C) 2019 by the author. Licensee MDPI, Basel, Switzerland. This article is an open access article distributed under the terms and conditions of the Creative Commons Attribution (CC BY) license (http://creativecommons.org/licenses/by/4.0/). 